\title{
Experimental study on the ability of different biogas level dual fuel spark ignition engine: Emission mitigation, performance, and combustion analysis
}

\author{
Suleyman Simsek ${ }^{1}$ (D), Samet Uslu ${ }^{2, *}$ (D), and Hatice Simsek ${ }^{3}$ \\ ${ }^{1}$ Department of Mechanical Engineering, Istanbul Aydın University, 34295 İstanbul, Turkey \\ ${ }^{2}$ Department of Mechanical Engineering, Karabuk University, 78050 Karabuk, Turkey \\ ${ }^{3}$ Department of Machinery and Metal Technologies, Tekirda $\breve{g}$ Namık Kemal University, 59030 Tekirdağ, Turkey
}

Received: 5 September 2021 / Accepted: 29 October 2021

\begin{abstract}
The major aim of the research is to investigate the ability of biogas as an alternative fuel for gasoline-powered Spark Ignition (SI) engine. In this study, biogas/gasoline fuel mixtures containing different ratios of biogas, gasoline, and biogas were tested in an SI engine with an increased compression ratio at different engine loads and constant engine speed. According to the comparison with gasoline, the utilization of biogas generally decreased the Brake Thermal Efficiency (BTE), while the Brake Specific Fuel Consumption (BSFC) rose. The lowest BTE and the highest BSFC were obtained with $100 \%$ biogas. Compared to gasoline, a decrease of $16.04 \%$ and an increase of $75.52 \%$ were observed, respectively. On the other hand, the use of biogas has improved all emissions. The best emission values were obtained with $100 \%$ biogas. Compared to gasoline, Carbon monOxide (CO), HydroCarbon ( $\mathrm{HC}$ ), and Nitrogen Oxide $\left(\mathrm{NO}_{\mathrm{x}}\right.$ ) emissions decreased by $56.42 \%$, $63 \%$, and $48.96 \%$, respectively. Finally, according to the results of the combustion analysis, the peak pressures were reduced with the utilization of biogas, and the position of the peak pressure shifted by $2^{\circ}$ to $3^{\circ}$ Crank Angle (CA). Compared to gasoline, the lowest pressure was obtained with $100 \%$ biogas, resulting in a reduction of approximately $24.69 \%$.
\end{abstract}

\section{Nomenclature}

$\begin{array}{ll}\text { Abbreviations } & \\ \text { BTE } & \text { Brake Thermal Efficiency } \\ \text { BSFC } & \text { Brake Specific Fuel Consumption } \\ \mathrm{CA} & \text { Crank Angle } \\ \mathrm{CH}_{4} & \text { Methane } \\ \mathrm{CO} & \text { Carbon monoxide } \\ \mathrm{CO}_{2} & \text { Carbon dioxide } \\ \mathrm{HC} & \text { HydroCarbon } \\ \mathrm{LPG} & \text { Liquefied Petroleum Gas } \\ \mathrm{MGT} & \text { Mean Gas Temperature } \\ \mathrm{NO} & \text { Nitrogen Oxide } \\ \mathrm{SI} & \text { Spark Ignition } \\ 100 \mathrm{G} & 100 \% \text { gasoline } \\ 100 \mathrm{Bio} & 100 \% \text { biogas } \\ 75 \mathrm{G}+25 \mathrm{Bio} & 75 \% \text { gasoline }+25 \% \text { biogas } \\ 50 \mathrm{G}+50 \mathrm{Bio} & 50 \% \text { gasoline }+50 \% \text { biogas } \\ 25 \mathrm{G}+75 \mathrm{Bio} & 25 \% \text { gasoline }+75 \% \text { biogas }\end{array}$

* Corresponding author: sametuslu@karabuk.edu.tr

\section{Introduction}

Energy has always had an important place in human life and energy needs must be met until the end of the world $[1,2]$. As a result of the developments in health and technology and the increasing quality of life compared to the past, the average human life span is getting longer, and the world population is increasing [3]. Accordingly, the energy demand also increases at the same rate $[4,5]$. Fossil fuels have been used mostly from past to present for the supply of energy need [6-8]. However, with the oil crisis in the 1970s, the fact that fossil fuels are exhaustible and that different energy sources are needed has been understood by the whole world $[9,10]$. Moreover, another and most important problem in the use of fossil fuels is air pollution [11, 12]. According to a study, it was stated that more than 8 million deaths occurred due to fossil fuel-related air pollution in 2018, and air pollution from the use of fossil fuels is responsible for 1 out of every 5 deaths worldwide [13]. Accordingly, studies on renewable, clean, and environmentally friendly fuels have gained momentum due to both the gradual decrease in fossil fuel reserves and their negative effects on the environment [14-16]. 
As an alternative to fossil fuels, many different materials have been used from past to present. Alcohols, biodiesels obtained from vegetable, animal, and waste products, Liquefied Petroleum Gas (LPG), and biogas are the main ones. Biogas is an odorless, colorless, and environmentally friendly fuel that is produced by the anaerobic fermentation of organic, agricultural, food residues, wastes, etc., into smaller molecules $[17,18]$. Biogas has many benefits compared to both fossil fuels and other fuels derived from biomass. Biogas technology performs a significant role in obtaining energy from organic materials and bringing waste materials to the soil, and after it is produced, the wastes do not disappear but turn into a much more valuable organic fertilizer [19, 20]. In addition, it has advantages such as easy transportation in pipelines, safe storage as compressed gas in high-pressure cylinders, not diluting the lubricating oil, and less harmful exhaust gas emission to the environment. Biogas also reduces the possibility of knocking due to its high auto-ignition temperature [21, 22]. Biogas generally contains 50-70\% methane $\left(\mathrm{CH}_{4}\right), 25-50 \%$ carbon dioxide $\left(\mathrm{CO}_{2}\right)$, and $1-5 \%$ of hydrogen. The rates of these gases may vary depending on effects such as bacteriological, raw material stocking rate, water content, temperature, and feeding source [23]. For the most suitable combustion conditions to be realized in the cylinder, at least $50 \%$ of $\mathrm{CH}_{4}$, which is the most basic content of biogas, must be present [24]. Biogas can be used on the internal combustion engine without the need for major structural changes $[25,26]$. Also, if a structural change is needed, it is much easier to modify a spark-ignition engine to run on biogas than a diesel engine [27, 28]. The control of the engine is carried out by changing the combination delivered to the engine by running the throttle valve located among the biogas mixer and the engine intake system.

Biogas can be used more efficiently in internal combustion engines by purifying the flammable gases in their content $[29,30]$. The usage of biogas in SI engines has become widespread in recent years. Hotta et al. [31] performed tests at several engine speeds to investigate the usability of raw biogas in SI engine. Compared to working with gasoline, they found a $66 \%$ increase in BSFC, a $12 \%$ decrease in BTE, and an $18 \%$ decrease in brake power, according to the results obtained with raw biogas. Then again, the authors indicated that while $\mathrm{CO}$ and $\mathrm{NO}_{\mathrm{x}}$ decreased by $40 \%$ and $81.5 \%, \mathrm{HC}$ and $\mathrm{CO}_{2}$ rose by $6.8 \%$ and $40 \%$. Moreover, they stated that the cylinder pressure obtained with the utilization of biogas is smaller than that of gasoline, the position of the peak cylinder pressure is at a lower level and appears much later. Simsek and Uslu [23] evaluated the effects of LPG and biogas use in terms of emissions, performance, and combustion in a single-cylinder, four-stroke SI engine by various throttle positions and compared with gasoline use. The tests were performed at different engine loads, at full throttle opening and two different throttle positions, at half throttle. The authors indicated that BSFC rose and BTE diminished with the utilization of LPG and biogas at both full gas opening and half gas opening. Then again, the authors indicated that all emissions were reduced in all throttle positions, using LPG and biogas. Finally, they stated that LPG and biogas have a decreasing effect on cylinder gas pressure. Kriaučiūnas et al. [32] tested biogas mixtures containing $0 \%, 20 \%, 40 \%$, and $50 \% \mathrm{CO}_{2}$ by volume in an SI engine at two separate spark timings. As stated by the results of the study, the authors indicated that increasing the $\mathrm{CO}_{2}$ concentration and using the fixed spark timing reduced in-cylinder pressure, BTE, and $\mathrm{NO}_{\mathrm{x}}$. On the other hand, they stated that optimum spark timing selection increases BTE as well as $\mathrm{HC}$ and $\mathrm{CO}_{2}$ emissions. Hotta et al. [25] investigated the effects of using biogas in a single-cylinder, four-stroke SI engine with a compression ratio of 10-14. The authors stated that by increasing the compression ratio from 10 to 12 , engine power and efficiency increased by $12.72 \%$ and $5.68 \%$, respectively. Moreover, the authors asserted that overall emissions increased with increasing compression ratio. The authors stated that, after a series of experiments, they concluded that the optimum compression ratio was 12 .

As mentioned in the above studies, the use of biogas in SI engines has mostly been limited to using 100\% biogas and changing various engine parameters. In the detailed literature review, it was concluded that there is a lack of studies related to the use of biogas in different volumetric ratios. From this point of view, in the present research, the impacts of the utilization of biogas at different rates were evaluated in a single-cylinder, four-stroke SI engine, at various engine load values, in terms of emission, performance and combustion indicators and compared with the use of $100 \%$ gasoline.

\section{Materials and methods}

Tests were performed on an air-cooled, 4-stroke, and singlecylinder Honda GX390 model SI engine. Since the octane number of the biogas is higher than that of gasoline, the compression ratio of the engine, which was originally 8.0:1, has been increased to $9.12: 1$ to obtain more efficiency. To enhance the compression ratio, the cylinder head cover is ground $0.8 \mathrm{~mm}$.

During the use of biogas in the engine, the flow pressure of the biogas is supplied with the support of the manometer and regulator on the tube. The flow of biogas was monitored through flow meters and digital displays positioned on the biogas line, and its passage through the one-way valve in a controlled manner was ensured. The definition of the engine air mass flow percentage with the manifold absolute pressure sensor and the proportional adjustment of the amount of fuel needed for optimal combustion were offered by a computer-controlled electronic control unit and the biogas coming out of the injector was proportionally mixed with the gasoline. A water-cooling system is positioned among the two flow meters to prevent a fire that may appear as a result of a backfire from the valves or a flame ignition for any reason.

In this study, experiments were carried out using five different test fuels as 100\% gasoline (100G), 100\% biogas (100Bio), $75 \%$ gasoline $+25 \%$ biogas $(75 \mathrm{G}+25 \mathrm{Bio}), 50 \%$ gasoline $+50 \%$ biogas $(50 \mathrm{G}+50 \mathrm{Bio})$, and $25 \%$ gasoline + $75 \%$ biogas $(25 \mathrm{G}+75 \mathrm{Bio})$, at six different engine loads 
$(500,1000,1500,2000,2500$, and $3000 \mathrm{~W})$ and constant engine speed (3000 rpm). The gasoline and biogas utilized in the tests are demonstrated in Table 1 , and the engine characteristics are demonstrated in Table 2. The schematic test system is presented in Figure 1.

\section{Results and discussion}

\subsection{Performance indicators}

BTE and BSFC are among the most important parameters for the evaluation of engine performance. BTE is a measure of how much of the energy produced by the combustion of fuel can be used beneficially. On the other hand, BSFC refers to the amount of fuel that requires to be consumed to obtain unit power per hour. The graphs of change of BTE and BSFC depending on the changing engine load and biogas ratio are shown in Figure 2. Both BTE and BSFC were negatively affected as the biogas content in the fuel increased. As seen in Table 1, while the octane number of gasoline is 91 , the octane number of biogas is 110. Although the higher-octane number brought about better BTE, the BTE decreased with the increase in the biogas ratio. The low density of biogas compared to gasoline also reduces its volumetric efficiency [29]. The low volumetric efficiency also causes a decrease in BTE. In addition, the low flame rate of biogas compared to gasoline affects BTE negatively. The highest BTE was obtained with 100G as $28.25 \%$ at $500 \mathrm{~W}$ load. The lowest BTE was determined as $22.20 \%$ with $100 \mathrm{Bio}$ and $3000 \mathrm{~W}$ load. There was an average of $16 \%$ reduction in all loads with 100Bio compared to 100G. In the comparison made in terms of BSFC, it can be seen that BSFC increases with increasing biogas. The lower calorific value of biogas compared to gasoline causes the BSFC to increase. While the highest BSFC was found to be $940 \mathrm{~g} / \mathrm{kWh}$ with $100 \mathrm{Bio}$ at $3000 \mathrm{~W}$ load, the lowest BSFC was determined as $440 \mathrm{~g} / \mathrm{kWh}$ at $2500 \mathrm{~W}$ load with 100G. Differences between BSFC improved with increasing engine load from $500 \mathrm{~W}$ to $3000 \mathrm{~W}$. While the difference between BSFC values at $500 \mathrm{~W}$ load was approximately $29 \%$, at $3000 \mathrm{~W}$ this difference was approximately $52 \%$.

\subsection{Environmental indicators}

It can be seen from all emission figures that emissions are positively affected by increasing biogas ratio. The variation of $\mathrm{HC}$ and $\mathrm{CO}$ emissions, which are products of incomplete combustion, depending on the biogas ratio and engine load are shown in Figures 3 and 4, respectively. Both HC and $\mathrm{CO}$ emissions decreased depending on the biogas ratio. As can be observed in Table 1, the carbon content of biogas is less than that of gasoline. In addition, the fact that biogas has a more homogeneous mixing ability with air compared to gasoline has commanded a decrease in $\mathrm{HC}$ and $\mathrm{CO}$ emissions. On the other hand, the variation of $\mathrm{NO}_{\mathrm{x}}$ emission depending on the biogas percentage and engine load is shown in Figure 5. Biogas, which has a small lower calorific value compared to gasoline, reduces the in-cylinder temperature and pressure, as well as the fuel combustion rate,
Table 1. Qualification of gasoline and biogas.

\begin{tabular}{lcc}
\hline Qualification & Gasoline & Biogas \\
\hline Chemical formulation & $\mathrm{C}_{8} \mathrm{H}_{18}-\mathrm{C}_{7} \mathrm{H}_{16}$ & $\mathrm{CH}_{4}-55.6 \%$ \\
& & $\mathrm{CO}_{2}-42.3 \%$ \\
& & $\mathrm{~N}_{2}-2.1 \%$ \\
Density at $15{ }^{\circ} \mathrm{C}\left(\mathrm{kg} / \mathrm{m}^{3}\right)$ & $720-775$ & 1.11 \\
Lower thermal value $(\mathrm{MJ} / \mathrm{kg})$ & 43.55 & 17.0 \\
Research octane number & 91 & 110 \\
Stoichiometric air $/$ fuel ratio & 14.7 & 5.67 \\
Autoignition temperature $\left({ }^{\circ} \mathrm{C}\right)$ & 257 & 650 \\
Flame velocity $(\mathrm{cm} / \mathrm{s})$ & 45 & 25 \\
The heat of evaporation $(\mathrm{kJ} / \mathrm{kg})$ & 330 & 500 \\
Evaporation temperature $\left({ }^{\circ} \mathrm{C}\right)$ & $20-200$ & -42 \\
\hline
\end{tabular}

Table 2. Qualification of engine.

\begin{tabular}{lc}
\hline Engine Qualification & \\
\hline Honda GX390 - 4-Stroke/single-cylinder & \\
Original compression ratio & $8.0: 1$ \\
Type of cooling & Air \\
Displacement $\left(\mathrm{cm}^{3}\right)$ & 389 \\
Power @ $3600 \mathrm{rpm}$ & $8.7 \mathrm{~kW}$ \\
Torque @ 2500 rpm & $26.5 \mathrm{~N} / \mathrm{m}$ \\
\hline
\end{tabular}

resulting in a decrease in $\mathrm{NO}_{\mathrm{x}}$ emissions $[32,33]$. In addition, increasing engine load increased $\mathrm{NO}_{\mathrm{x}}$ emissions in all test fuels. Growing engine load improved the in-cylinder temperature and $\mathrm{NO}_{\mathrm{x}}$ emissions. Because the formation of $\mathrm{NO}_{\mathrm{x}}$ emissions accelerates with growing in-cylinder temperature. Currently, HC emission has decreased in all fuels with increasing load. With biogas-containing fuels, the decreasing trend of $\mathrm{HC}$ with increasing load indicates improved combustion compared to gasoline. Biogas can easily mix by air and form a homogeneous air-fuel combination. Also, by the boost of engine load, the volumetric efficiency of the biogas-fueled engine was smaller compared to gasoline. The weak mixture concentration given to the engine causes better combustion of the air-fuel mixture and a smaller amount of $\mathrm{HC}$ is produced by growing engine load. In addition, while the $\mathrm{CO}$ concentration with growing engine load in the fuel containing $50 \%$ biogas remained almost balanced, the increased engine load in the biogas ratios exceeding $50 \%$ caused a decrease as in the $\mathrm{HC}$ emission.

\subsection{Combustion indicators}

Cylinder gas pressure changes according to the crank angle obtained by using fuel mixtures containing both gasoline and different proportions of biogas in the SI engine are shown in Figure 6. It can be seen that the peak pressure obtained with biogas-containing fuels is lower than that of gasoline and is changed from $2^{\circ}$ to $3^{\circ} \mathrm{CA}$. Although the 


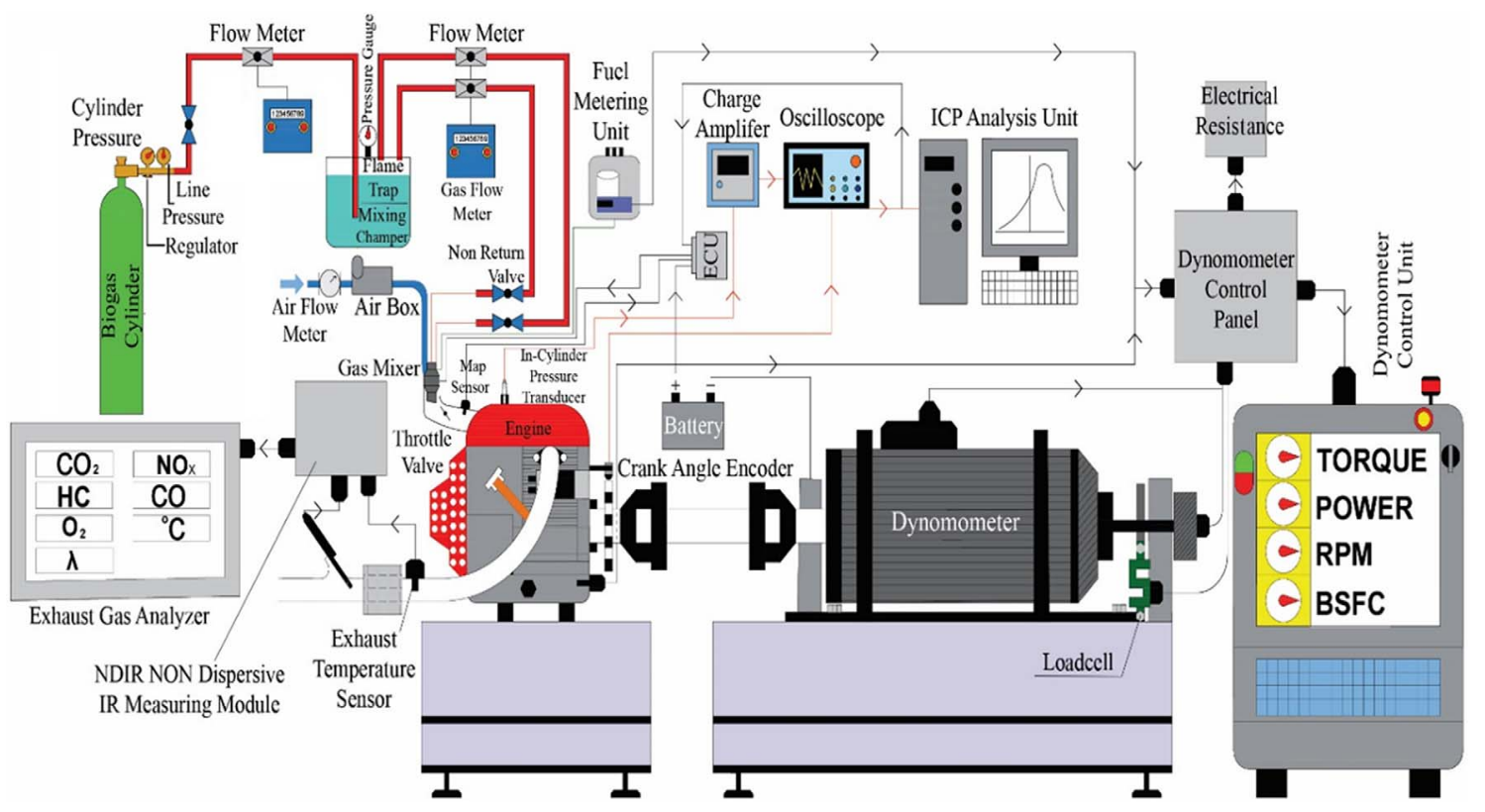

Fig. 1. Schematic test setup.

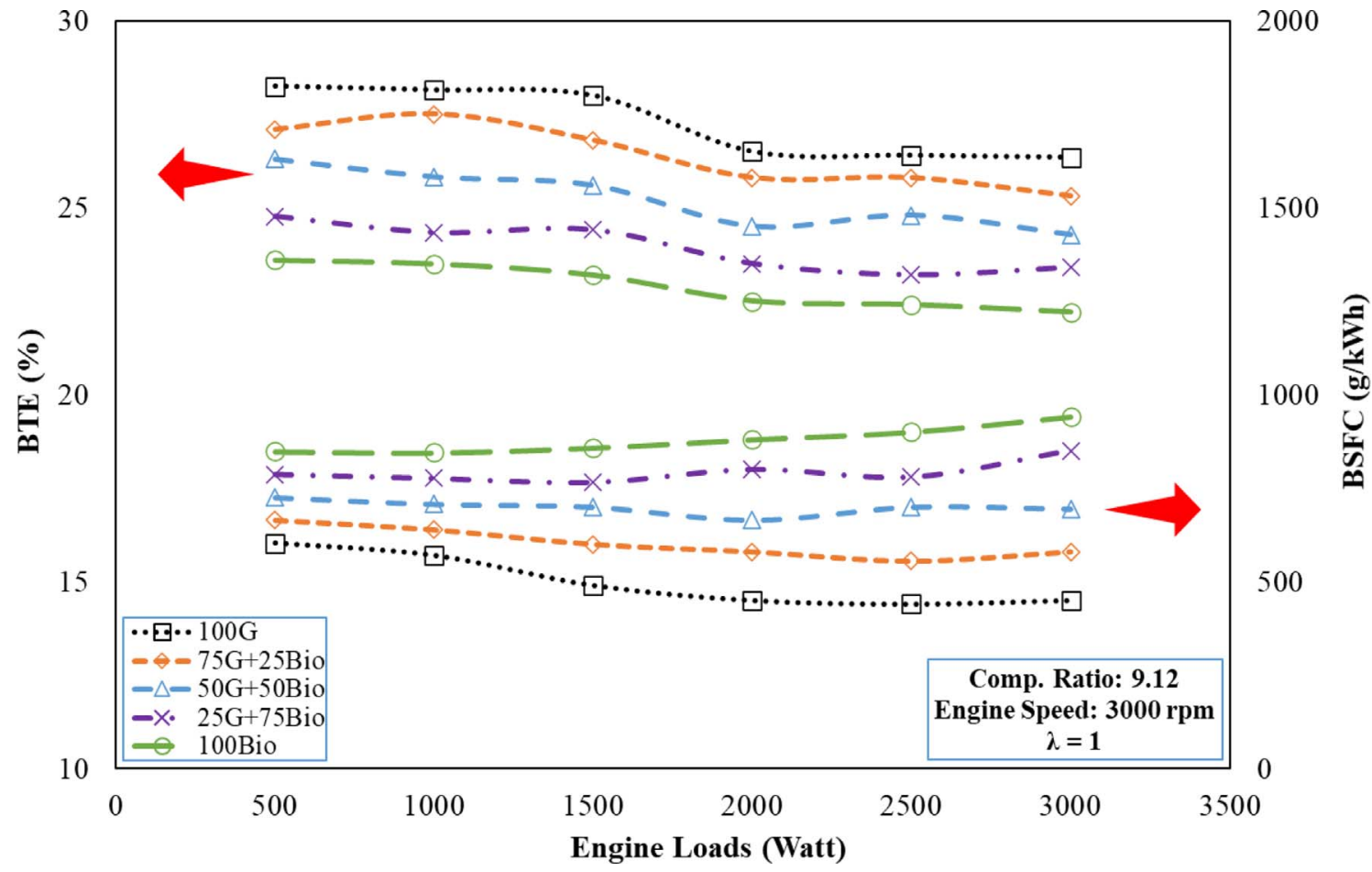

Fig. 2. Variation of BTE and BSFC according to biogas ratio and engine load.

gas pressure peak remained almost the same due to the increasing biogas ratio, the gas pressure values decreased. This was due to the variation in spark timing and the much slower combustion rate of biogas compared to gasoline. The maximum pressure was obtained with $100 \mathrm{G}$ as 32 bar at $372^{\circ} \mathrm{CA}$, while the minimum pressure was determined with $100 \mathrm{Bio}$ as 24.1 bar at $375^{\circ} \mathrm{CA}$. The cylinder gas pressure obtained with 100Bio was approximately 


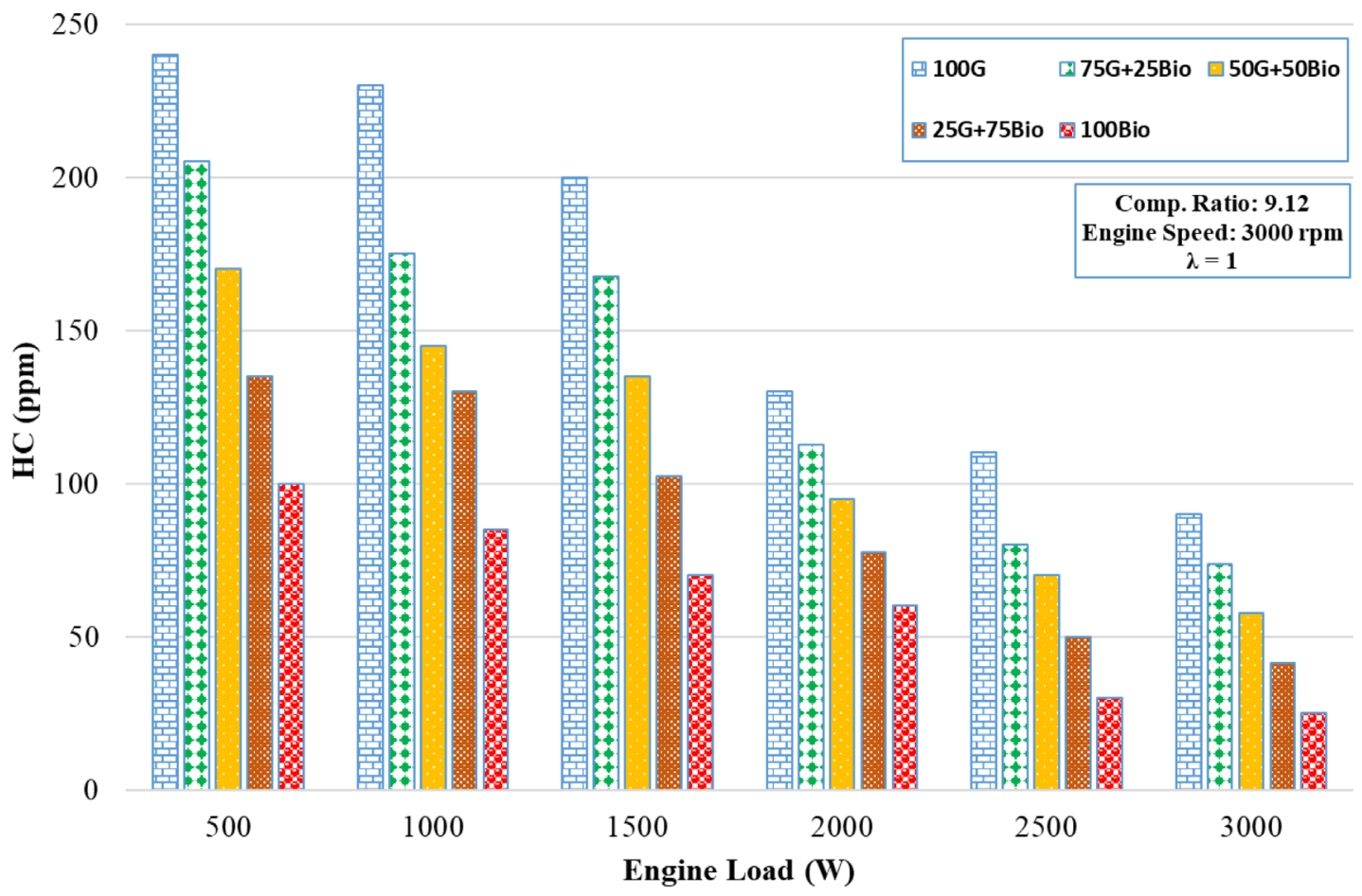

Fig. 3. Variation of HC emission according to biogas ratio and engine load.

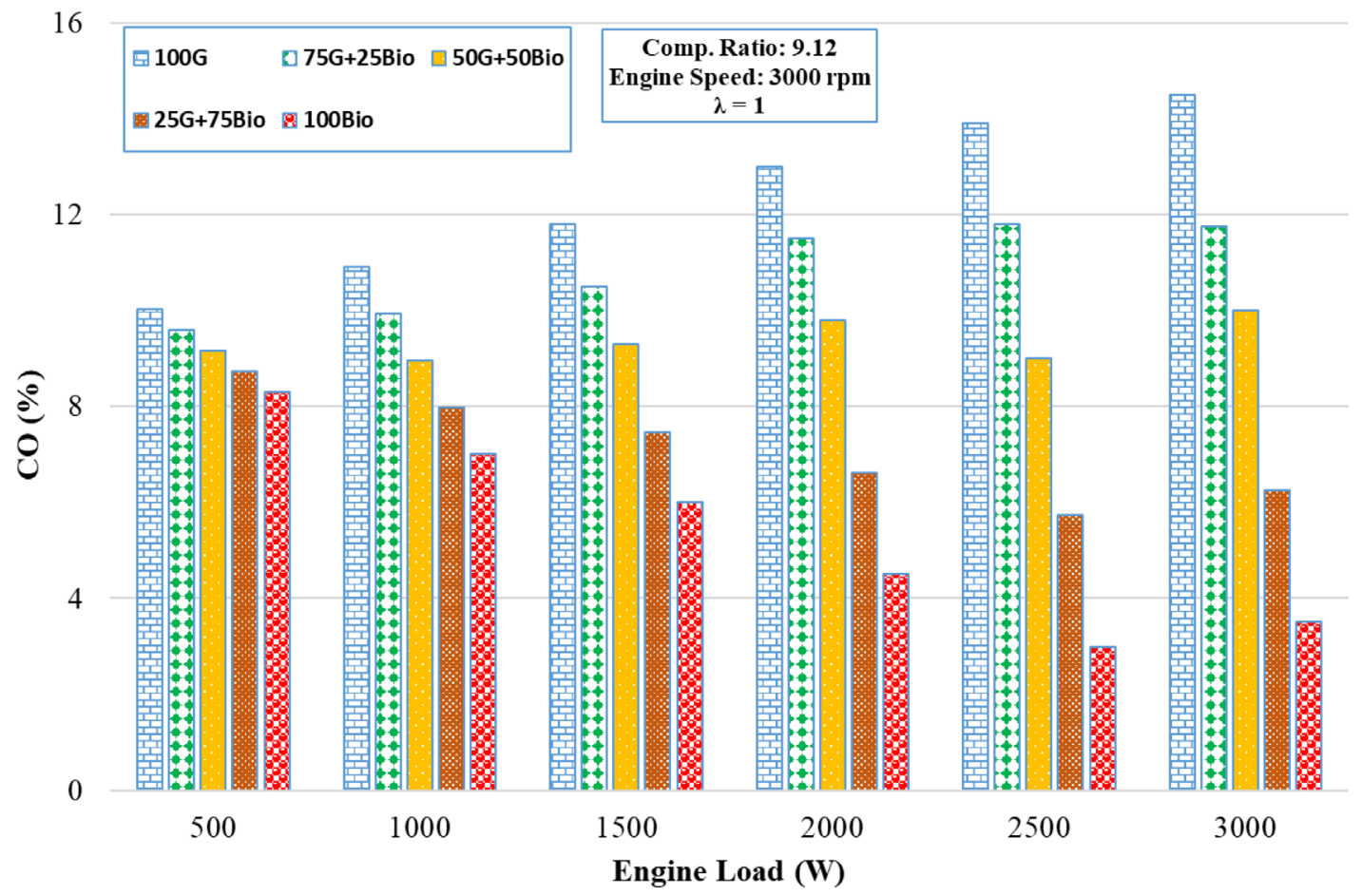

Fig. 4. Variation of $\mathrm{CO}$ emission according to biogas ratio and engine load.

$24.69 \%$ lower than that of 100G. On the other hand, the pressures obtained with $75 \mathrm{G}+25 \mathrm{Bio}, 50 \mathrm{G}+50 \mathrm{Bio}$, and $25 \mathrm{G}+75$ Bio fuels were determined as $29.90,28.20$, and 25.80 bar, respectively. Compared to the pressure value obtained with $100 \mathrm{G}$, there was a decrease of $6.56 \%$, $11.88 \%$, and $19.38 \%$, respectively.

The change of the Mean Gas Temperature (MGT) in the use of gasoline and biogas-containing fuel mixtures in the SI 


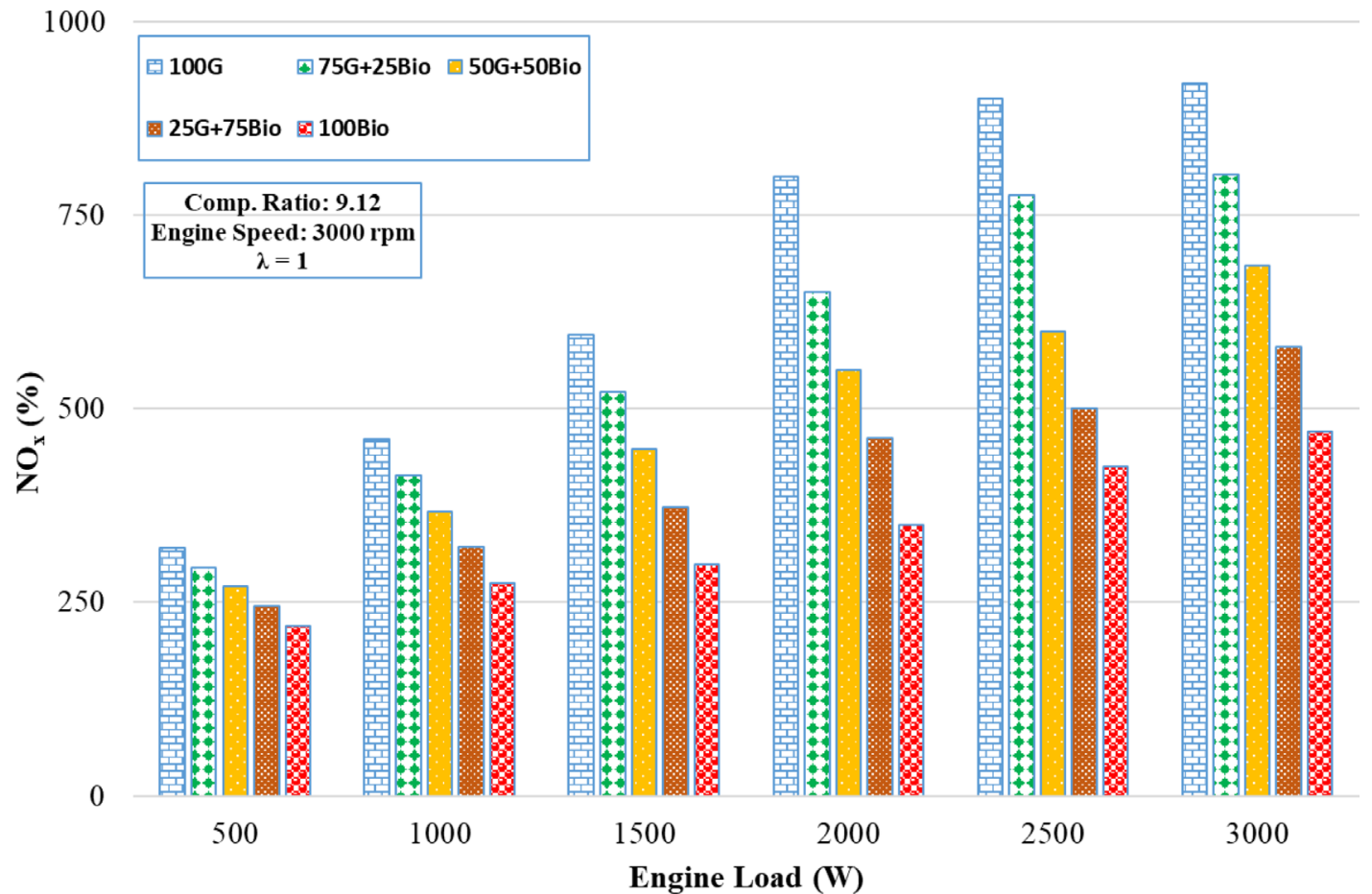

Fig. 5. Variation of $\mathrm{NO}_{\mathrm{x}}$ emission according to biogas ratio and engine load.

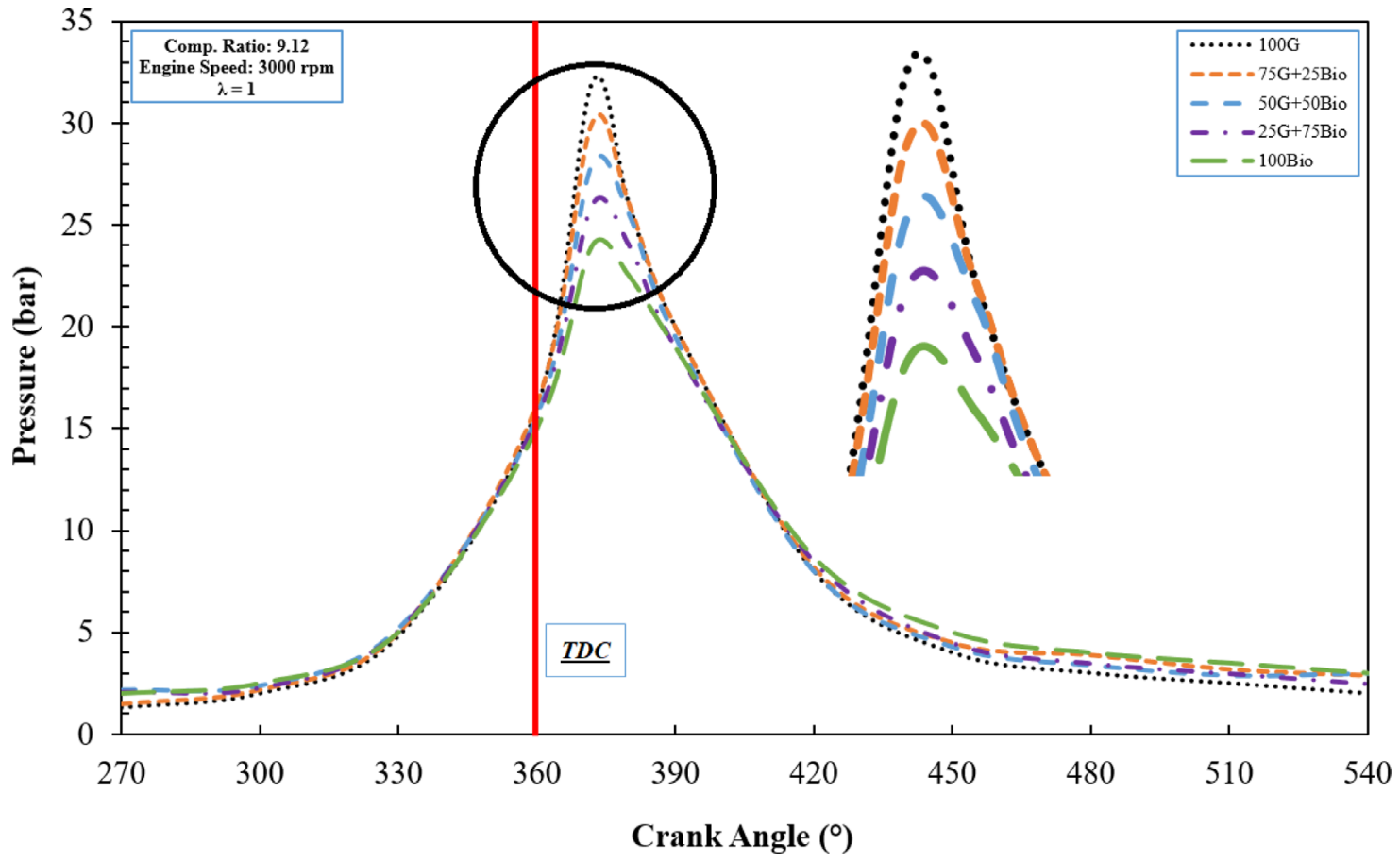

Fig. 6. Variation of cylinder gas pressure according to crank angle.

engine is shown in Figure 7. It is seen that the MGT of the SI engine is always lower in the expansion stroke of the biogas fueled combustion compared to the gasoline-fueled combustion. It can be said that this is owing to the small energy conversion efficiency of biogas due to its lower calorific value compared to gasoline. In addition, it has been detected that the MGT of the engine in the compression stroke of the engine is greater than that of gasoline in the use of fuels 


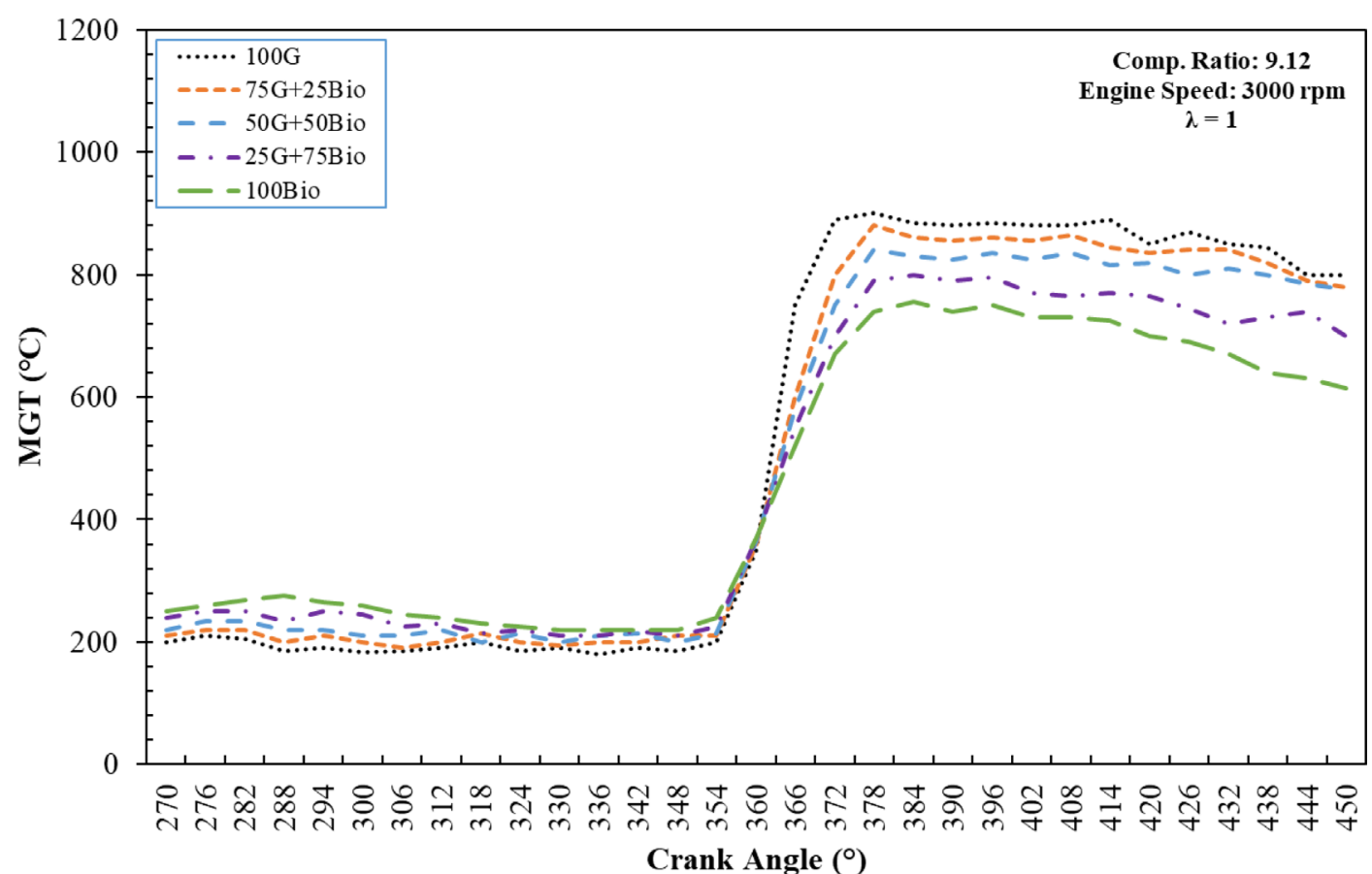

Fig. 7. Variation of MGT according to crank angle.

containing biogas. The reason for this can be explained as the higher heat transfer rate in the use of gasoline.

\section{Conclusion}

The attributes of a single-cylinder, SI engine operating by biogas and biogas-gasoline fuel mixtures were investigated experimentally, and compared with the gasoline operation, the following inferences were obtained:

- In the use of biogas-containing test fuels $75 \mathrm{G}+25 \mathrm{Bio}$, $50 \mathrm{G}+50 \mathrm{Bio}, 25 \mathrm{G}+25 \mathrm{Bio}$, and 100Bio, the SI engine produced an average of $3.27 \%, 7.55 \%, 12.26 \%$, and $16.04 \%$ less BTE than gasoline, respectively.

- At all loads, the BSFC value increased with the use of biogas compared to gasoline, and this increase increased with the increasing biogas ratio. The BSFC values obtained with $75 \mathrm{G}+25 \mathrm{Bio}, 50 \mathrm{G}+50 \mathrm{Bio}$, $25 \mathrm{G}+25 \mathrm{Bio}$, and $100 \mathrm{Bio}$ were on average $20.48 \%$, $39.63 \%, 58.47 \%$, and $75.52 \%$ higher, respectively, compared to gasoline.

- The utilization of biogas has reduced $\mathrm{HC}, \mathrm{CO}$, and $\mathrm{NO}_{\mathrm{x}}$ emissions, and this decrease has increased from $25 \%$ biogas to $100 \%$ biogas. With the use of $75 \mathrm{G}+25 \mathrm{Bio}, 50 \mathrm{G}+50 \mathrm{Bio}, 25 \mathrm{G}+25 \mathrm{Bio}$, and 100Bio fuels, an average of $12.22 \%, 24.16 \%, 42.32 \%$, and $56.42 \%$ improvement in CO emissions has been achieved, respectively, compared to $100 \mathrm{G}$. In addition, HC emissions decreased by $18.63 \%, 32.75 \%$, $46.38 \%$, and $63 \%$, respectively. The improvement in $\mathrm{NO}_{\mathrm{x}}$ emissions was realized as $13.46 \%, 26.92 \%$, $37.88 \%$, and $48.96 \%$ on average, respectively.
- The peak pressure obtained with biogas-containing fuels is lower than that of gasoline and is changed from $2^{\circ}$ to $3^{\circ} \mathrm{CA}$. Compared to the pressure value obtained with $100 \mathrm{G}$, there was a decrease of $6.56 \%$, $11.88 \%, 19.38 \%$, and $24.69 \%$ with $75 \mathrm{G}+25 \mathrm{Bio}$, $50 \mathrm{G}+50 \mathrm{Bio}, 25 \mathrm{G}+25 \mathrm{Bio}$, and 100Bio, respectively.

In general, it can be said that the innovative approach of combining promising biogas with gasoline in different proportions is a very effective methodology. On the other hand, a more comprehensive study is planned by opting for optimization applications to determine the optimum biogas ratio and engine operating conditions with high accuracy.

\section{References}

1 Canan A., Calhan R., Ozkaymak M. (2021) Investigation of the effects of different slags as accelerant on anaerobic digestion and methane yield, Biomass Conv. Bioref. 11, 1395-1406.

2 Rajak U., Nashine P., Verma T.N. (2020) Effect of spirulina microalgae biodiesel enriched with diesel fuel on performance and emission characteristics of CI engine, Fuel 268, 117305.

3 Simsek S., Uslu S., Simsek H., Uslu G. (2021) Improving the combustion process by determining the optimum percentage of liquefied petroleum gas (LPG) via response surface methodology (RSM) in a spark ignition (SI) engine running on gasoline-LPG blends, Fuel Process. Technol. 221, 106947.

4 Biswal A., Kale R., Balusamy S., Banerjee R., Pankaj K. (2019) Lemon peel oil as an alternative fuel for GDI engines: A spray characterization perspective, Renew. Energy 142, 249-263. 
5 Simsek S., Uslu S. (2020) Determination of a diesel engine operating parameters powered with canola, safflower and waste vegetable oil based biodiesel combination using response surface methodology (RSM), Fuel 270, 117496.

6 Mujtaba M.A., Kalam M.A., Masjuki H.H., Gul M., Soudagar M.E.M., Ong H.C., Ahmed W., Atabani A.E., Razzaq L., Yusoff M. (2020) Comparative study of nanoparticles and alcoholic fuel additives-biodiesel-diesel blend for performance and emission improvements, Fuel 279, 118434.

7 Zhen X., Wang Y., Liu D. (2020) Bio-butanol as a new generation of clean alternative fuel for SI (spark ignition) and CI (compression ignition) engines, Renew. Energy 147, 1, 2494-2521.

8 Yesilyurt M.K., Aydin M. (2020) Experimental investigation on the performance, combustion and exhaust emission characteristics of a compression-ignition engine fueled with cottonseed oil biodiesel/diethyl ether/diesel fuel blends, Energy Conv. Manage. 205, 112355.

9 Sun C.S., Liu Y., Qiao X., Ju D., Tang Q., Fang X., Zhou F. (2020) Experimental study of effects of exhaust gas recirculation on combustion, performance, and emissions of DMEbiodiesel fueled engine, Energy 197, 1172333.

10 Simsek S., Uslu S., Coştu R. (2021) A novel approach to study the effect of motor silk-added pyrolysis tire oil on performance and emission characteristics of a diesel engine, Fuel 288, 119668.

11 Jagtap S.P., Pawar A.N., Lahane S. (2020) Improving the usability of biodiesel blend in low heat rejection diesel engine through combustion, performance and emission analysis, Renew. Energy 155, 628-644.

12 Fayad M.A., Tsolakis A., Martos F.J. (2020) Influence of alternative fuels on combustion and characteristics of particulate matter morphology in a compression ignition diesel engine, Renew. Energy 149, 962-969.

13 Vohra K., Vodonos A., Schwartz J., Marais E.A., Sulprizio M.P., Mickley L.J. (2021) Global mortality from outdoor fine particle pollution generated by fossil fuel combustion: Results from GEOS-Chem, Environ. Res. 195, 110754.

14 Xiao H., Guo F., Wang R., Yang X., Li S., Ruan J. (2020) Combustion performance and emission characteristics of diesel engine fueled with iso-butanol/biodiesel blends, Fuel 268, 117387.

15 Simsek S., Uslu S. (2020) Investigation of the effects of biodiesel/2-ethylhexyl nitrate (EHN) fuel blends on diesel engine performance and emissions by response surface methodology (RSM), Fuel 275, 118005.

16 Yilmaz E. (2019) Investigation of the effects of diesel-fusel oil fuel blends on combustion, engine performance and exhaust emissions in a single cylinder compression ignition engine, Fuel 255, 115741.

17 Li Y., Liu H., Yan F., Su D., Wang Y., Zhou H. (2017) Highcalorific biogas production from anaerobic digestion of food waste using a two-phase pressurized biofilm (TPPB) system, Bioresour. Technol. 224, 56-62.

18 Ruiz J.A., Juarez M.C., Morales M.P., Munoz P., Mendivil M.A. (2013) Biomass gasification for electricity generation: Review of current technology barriers, Renew. Sustain. Energy Rev. 18, 174-183.
19 Diamantis V., Eftaxias A., Stamatelatou K., Noutsopoulos C., Vlachokostas C., Aivasidis A. (2021) Bioenergy in the era of circular economy: Anaerobic digestion technological solutions to produce biogas from lipid-rich wastes, Renew. Energy 168, 438-447.

20 Tallou A., Salcedo F.P., Haouas A., Jamali M.Y., Atif K., Aziz F., Amir S. (2020) Assessment of biogas and biofertilizer produced from anaerobic co-digestion of olive mill wastewater with municipal wastewater and cow dung, Environ. Technol. Innov. 20, 101152.

21 Tippayawong N., Thanompongchart P. (2010) Biogas quality upgrade by simultaneous removal of $\mathrm{CO}_{2}$ and $\mathrm{H}_{2} \mathrm{~S}$ in a packed column reactor, Energy 35, 12, 4531-4535.

22 Porpatham E., Ramesh A., Nagalingam B. (2013) Effect of swirl on the performance and combustion of a biogas fuelled spark ignition engine, Energy Conv. Manage. 76, 463-471.

23 Simsek S., Uslu S. (2020) Investigation of the impacts of gasoline, biogas and LPG fuels on engine performance and exhaust emissions in different throttle positions on SI engine, Fuel 279, 118528.

24 Jung C., Park J., Song S. (2015) Performance and $\mathrm{NO}_{\mathrm{x}}$ emissions of a biogas-fueled turbocharged internal combustion engine, Energy 86, 186-195.

25 Hotta S.K., Sahoo N., Mohanty K., Kulkarni V. (2020) Ignition timing and compression ratio as effective means for the improvement in the operating characteristics of a biogas fueled spark ignition engine, Renew. Energy 150, 854-867.

26 Kalsi S.S., Subramanian K.A. (2017) Effect of simulated biogas on performance, combustion and emissions characteristics of a bio-diesel fueled diesel engine, Renew. Energy 106, 78-90.

27 Nadaleti W.C., Przybyla G. (2018) Emissions and performance of a spark-ignition gas engine generator operating with hydrogen-rich syngas, methane and biogas blends for application in southern Brazilian rice industries, Energy 154, 38-51.

28 Verma S., Das L.M., Kaushik S.C. (2017) Effects of varying composition of biogas on performance and emission characteristics of compression ignition engine using exergy analysis, Energy Conv. Manage. 138, 346-359.

29 Sadiq R., Iyer R.C. (2020) Experimental investigations on the influence of compression ratio and piston crown geometry on the performance of biogas fuelled small spark ignition engine, Renew. Energy 146, 997-1009.

30 Feroskhan M., Ismail S. (2017) A review on the purification and use of biogas in compression ignition engines, Int. J. Autom. Mech. Eng. 14, 3, 4383-4400.

31 Hotta S.K., Sahoo N., Mohanty K. (2019) Comparative assessment of a spark ignition engine fueled with gasoline and raw biogas, Renew. Energy 134, 1307-1319.

32 Kriaučiūnas D., Pukalskas S., Rimkus A., Barta D. (2021) Analysis of the influence of $\mathrm{CO}_{2}$ concentration on a spark ignition engine fueled with biogas, Appl. Sci. 11, 14, 6379.

33 Kim Y., Kawahara N., Tsuboi K., Tomita E. (2016) Combustion characteristics and $\mathrm{NO}_{\mathrm{X}}$ emissions of biogas fuels with various $\mathrm{CO}_{2}$ contents in a micro co-generation spark-ignition engine, Appl. Energy 182, 539-547. 